\title{
Large Plains Garter Snake Found
}

\author{
by R. W. Nero, S.M.N.H.
}

A Plains Garter Snake (Thamnophis radix) found by myself and Ralph D. Carson on October 15, 1950, in an aspen grove near McLean, Saskatchewain, measures 43 inches in total length and is apparently the largest recorded individual of this species. According to Roger Conant (1958. A Field Guide to Reptiles and Amphibians) 40 inches is the maximum record. Francis R. Cook, Curator of Herpetology, National Museum of Canadia, reports a $401 / 2$ inch specimen collected near Souris, Manitiba, this past summer as the largest known to him. He suggests that our northern specimens are possibly slightly larger than those found elsewhere, but he is careful to point out that a large series will be necessary to establish this. Our specimen may be a particularly old individual since reptiles and amphibians continue to grow in size throughout their life. Although October 15 was a rather cool and windy though sunny day the portion of the woods where we found the snake was sheltered and warm and the snake was very active. We would be interested in receiving specimens of large size and would like to hear from others who may have recorded large Plains Garter Snakes.

Two other species of garter snake are found in Saskatchewan. The Wandering Garter Snake (Thamnophis elegans vagrans) is a grayish species found in the arid parts. of southwestern Saskatchewan and is rather uncommon. The Red-sided Garter Snake (Thamnophis sirtalis) is similar to the Plains Garter Snake but has a red nather than a yellow stripe on each side and is found throughout southern and eastern Saskatchewan. A mimeographed check list of the reptiles and amphilbians of Saskatchewan may be abtained free of charge upon request to the Extension Division, Sask. Museum of Natural History, Regina.

\section{LETTERS}

\section{MY VISIT WITH THE HAMERSTROMS}

On July 13,1960 , I left Kindersley and travelled by rail to Plainfield, Wisconsin, on the invitation of Dr. and Mrs. F. N. Hamensitirom, Jr. I arrived at the "camp," as they prefer to call it, late on the evening of July 15 and was hustled off to bed.

I found that the camp is a wonderfull place for observing birds. It is an old estate with many trees, some of which have reached a colossal size. One can count as many as fifteen species of birds in song during the early morning.

Both Fran and her husband "Hammy" are invigorating, clever, and thorough ornithologists. They are experts on gallinaceous fowl and are highly interested in birds of prey as a hobby. They are employed by the Wisconsin Conservation Department to study the Prairie Chicken. In the spring booming season the camp becomes a hotel. Mrs. Hamerstrom had 488 house guests in six weeks during the spring booming season of 1960 . These guests assist the Hamerstroms in their research by observing different booming grounds from blinds and recording certain data. Few of us have an opportunity to observe this species doing its courtship dance since it has almost vanished from Saskatchewan.

The majority of my time was spent assisting Mrs. Hamerstrom with her harrier study. We trapped nesting pairs at the nest, banded them and imped colored plumes into the wings and meleased them. Each pair had its own colors. Through this study Mrs. Hamerstrom has learned much about this species, its mating over several 